\title{
Timing of tracheostomy in acute traumatic spinal cord injury: a systematic review and meta-analysis
}

\author{
Shaurya Taran \\ University of Toronto \\ JM Singh \\ University of Toronto \\ Demetrios James Kutsogiannis \\ University of Alberta \\ Victoria McCredie \\ University of Toronto
}

Sarah Foran ( $\nabla$ sarah.foran@mail.utoronto.ca )

University of Toronto Faculty of Medicine: University of Toronto Temerty Faculty of Medicine https://orcid.org/0000-0002-5054-6621

\section{Research}

Keywords: acute spinal cord injury, traumatic spinal cord injury, critical care, tracheostomy timing, mechanical ventilation

Posted Date: January 29th, 2021

DOI: https://doi.org/10.21203/rs.3.rs-157790/v1

License: (c) (1) This work is licensed under a Creative Commons Attribution 4.0 International License. Read Full License

Version of Record: A version of this preprint was published at Journal of Trauma and Acute Care Surgery on September 9th, 2021. See the published version at https://doi.org/10.1097/TA.0000000000003394. 


\section{Abstract}

Background Patients with acute traumatic cervical or high thoracic level spinal cord injury (SCl) typically require mechanical ventilation (MV) during their acute admission. Placement of a tracheostomy is preferred when prolonged weaning from MV is anticipated. However, the optimal timing of tracheostomy placement in patients with acute traumatic SCI remains uncertain. We systematically reviewed the literature to determine the effects of early versus late tracheostomy or prolonged intubation in patients with acute traumatic SCl on important clinical outcomes.

Methods Six databases were searched from their inception to January 2020. Conference abstracts from relevant proceedings and the gray literature were searched to identify additional studies. Data was obtained by two independent reviewers to ensure accuracy and completeness. The quality of observational studies was evaluated using the Newcastle Ottawa Scale (NOS).

Results Seventeen studies (2,804 patients) met selection criteria, 14 of which were published after 2009. Meta-analysis showed that early tracheostomy was not associated with decreased short-term mortality (risk ratio [RR] 0.84; 95\% confidence interval [CI] 0.39 to $1.79 ; p=0.65 ; n=2,072$ ), but was associated with a reduction in MV duration (mean difference [MD] 13.1 days; $95 \% \mathrm{Cl}-6.70$ to $-21.11 ; p=0.0002$; $n=855$ ), intensive care unit (ICU) length of stay (MD - 10.20 days; $95 \% \mathrm{Cl}-4.66$ to $-15.74 ; \mathrm{p}=0.0003 ; n=855)$, and hospital length of stay (MD -7.39 days; $95 \% \mathrm{Cl}-3.74$ to $-11.03 ; p<0.0001 ; n=$ 423). Early tracheostomy was also associated with a decreased incidence of ventilator-associated pneumonia (VAP) and tracheostomy-related complications (RR $0.86 ; 95 \% \mathrm{Cl} 0.75$ to $0.98 ; \mathrm{p}=0.08 ; \mathrm{n}=2,043$ and $\mathrm{RR} 0.08 ; 95 \% \mathrm{Cl}-0.01$ to $-0.15 ; \mathrm{p}=0.02 ; \mathrm{n}=812$ respectively). The majority of studies ranked as good methodologic quality on the NOS.

Conclusions Early tracheostomy in patients with acute traumatic SCI may reduce duration of mechanical ventilation, length of ICU stay, and length of hospital stay. Current studies highlight the lack of high-level evidence to guide the optimal timing of tracheostomy in acute traumatic SCl. Future research should seek to understand whether early tracheostomy improves patient comfort, decreases duration of sedation and improves long-term outcomes.

\section{PROSPERO registration number: CRD42020162488}

\section{Background}

Patients with acute traumatic spinal cord injury $(\mathrm{SCl})$ at the cervical or high thoracic level typically experience severe respiratory complications, resulting in the need for mechanical ventilation (MV) [1-3]. In cervical SCl, patients have significantly reduced vital capacity and ventilatory reserve because of interruption of neural pathways to the diaphragm and respiratory muscles of the chest and abdomen, leading to a restrictive ventilatory impairment, while the loss of sympathetic innervation results in increased bronchial tone and mucous secretions [4][5]. Many patients therefore require translaryngeal intubation with placement of an endotracheal tube and initiation of invasive MV. In thoracic SCl, respiratory insufficiency and mechanical ventilation are more commonly related to direct chest trauma and pulmonary injury [1][6].

Tracheostomy is typically preferred in situations where prolonged MV is required or weaning from MV is anticipated to be prolonged [7][2]. Tracheostomy may facilitate weaning by reducing airway resistance and may prevent complications from prolonged orotracheal intubation, such as ulceration, granulation tissue formation, subglottic edema, and tracheal and laryngeal stenosis [8-10]. Other posited benefits of tracheostomy include improved patient comfort, swallowing, early phonation, and ease of access for tracheal suctioning to manage respiratory secretions [2][11][12]. It is, however, an invasive procedure with the potential for multiple complications [13-15]. The decision to convert a translaryngeal intubation to a tracheostomy therefore requires anticipation of the expected duration $\mathrm{MV}$ and a careful assessment of the benefits and risks of the procedure.

For patients with acute traumatic $\mathrm{SCl}$, there is no consensus on the optimal time to perform a tracheostomy [16]. Clinicians may wait in the hope that the patient will be extubated or may delay the placement of a tracheostomy following anterior cervical spine fixation [17]. Guidelines for the respiratory management after SCl were published in 2005, however these recommendations were not specific to the acute care setting, focused mainly on evidence from non-critically ill SCl patients, and did not provide recommendations on the optimal timing of tracheostomy [18]. Although individual studies have investigated whether early (within seven days of intubation) or late (after seven days of intubation) tracheostomy improves outcomes, including mortality, ventilator-associated pneumonia, and length of hospital and intensive care unit (ICU) stay, the results remain inconclusive. Additionally, whether more patient-orientated outcomes, such as the ability to speak or maintain oral intake, are improved by early tracheostomy remain unknown. We performed a systematic review to evaluate and synthesize evidence regarding the timing of tracheostomy in patients with acute traumatic SCl.

\section{Methods}

This systematic review was performed in accordance with PRISMA (Preferred Reporting Items for Systematic Reviews and Meta-Analyses) and guided by an a priori protocol registered with PROSPERO (ID: CRD42020162488) [19].

\section{Search Strategy}


Studies were identified by searching MEDLINE, EMBASE, CINAHL, Scopus, Web of Science and the Cochrane Central Register of Controlled Trials (CENTRAL) from their inception to January 2020, with no limitations on time or language of publication. An experienced health sciences librarian assisted in development of the strategy (Supplemental Appendix 1). The reference lists of retrieved articles were investigated to identify additional studies. Abstracts were searched from the conference proceedings listed in Supplemental Appendix 1, within the past 10 years, and the gray literature was searched using Google Scholar. A sensitivity analysis was performed utilizing 10 pre-identified studies (Supplemental Appendix 2).

\section{Study Selection}

Studies were initially screened for eligibility by title, keywords, and abstract using the Covidence software (Melbourne, Australia) by the primary reviewer (S.J.F) [20]. Studies passing the initial screen were subsequently reviewed in full by two reviewers (S.J.F, S.T.) to confirm eligibility for inclusion. Studies included i) randomized controlled trials (RCT) that compared either the timing of tracheostomy, or tracheostomy and prolonged intubation, in patients with acute $\mathrm{SCl}$, and ii) cohort studies that included acute SCl patients receiving early tracheostomy or late tracheostomy/prolonged intubation while admitted in the ICU. Differences between the two reviewers (S.J.F. and S.T.) regarding eligible studies were resolved in consultation with a third reviewer (V.A.M.).

\section{Data Abstraction and Quality Assessment}

Data was independently extracted from included studies by two reviewers (S.J.F and S.T.) using a standardized data collection form (Supplemental Appendix 3). The Newcastle-Ottawa Scale (NOS) was used to assess the quality of included studies (Supplemental Appendix 4) [21]. All of the studies, with the exception of 1 case series, were cohort studies and thus the NOS was used as it is one of two tools recommended by the Cochrane Handbook to assess the quality of nonrandomized studies of interventions [22] (Table 2 and Table 3).

\section{Outcomes}

The primary outcome was short-term mortality, defined as mortality in the ICU or hospital. Secondary outcomes included long-term mortality (defined as death at hospital discharge, 6 months or 1-2 years following the acute illness), duration of mechanical ventilation, ICU length of stay (LOS), hospital LOS, duration of sedation, incidence of ventilator-associated pneumonia (VAP), rate of tracheostomy procedures performed and tracheostomy-associated complications (airway stenosis, bleeding, stoma site infection, tracheoesophageal fistula, tracheal granuloma, mediastinal abscess, vocal cord dysfunction and dysphonia), ICU-associated complications (deep vein thrombosis, pulmonary embolus, decubitus ulcers), long term benefits (quality of life measures including Life Satisfaction Index, Beck Depression Inventory), time to swallowing and phonation, as well as time to decannulation (Supplemental Appendix 5). Analyses of the following subgroups were planned: spinal cord damage (level of injury and ASIA grade/complete versus incomplete), patients with concomitant injuries, mechanism of injury, management in a specialized SCI versus non-specialized SCl centre, patients who underwent anterior cervical spine fixation approach versus posterior approach, type of tracheostomy (percutaneous versus open surgical), patient demographics (age $<18$ versus $>18$ and $<65$ versus $>65$, smokers versus non-smokers, females versus males), timing of early tracheostomy (within 4,7 or 10 days), year of publication (studies published within the last five years versus older publications), and type of publication (studies published in peerreviewed journals versus others. Finally, patient and surgical factors associated with the timing of tracheostomy were explored.

\section{Quantitative Data Synthesis}

Meta-analysis was performed using Review Manager 5.4. The qualitative terms of 'early' and 'late' tracheostomy as defined by the researchers of each study were used in the analysis. Dichotomous data was analyzed using the DerSimonian and Laird random effects model to produce the effect measure as a risk ratio (RR). Continuous data was analyzed using an inverse variance random effects model and reported as the mean difference (MD). A $95 \%$ study confidence interval $(\mathrm{Cl})$ was utilized for the analysis of all outcomes. Heterogeneity was assessed using the ${ }^{2}$ statistic, the Chi-squared test for homogeneity, and visual inspection of the forest plots. A z test of interaction was performed for all subgroup comparisons, which tests the null hypothesis that the treatment effects in each subgroup are the same.

\section{Results}

\section{Literature Search}

The database search yielded 3098 citations. One study was found by gray literature search, three were retrieved from the reference lists of the included studies, and one abstract was included following a search of conference proceedings. In total, 17 studies with 2,804 patients met our inclusion criteria and were included in this systematic review (Figure 1). 
The characteristics of included studies are summarized in Table 1. Studies differed in their definitions of early and late tracheostomy (Supplemental Appendix 6), although the majority utilized a range of $\leq 7$ days (from either injury, intubation, or surgery) for early tracheostomy [23-33]. In one study, early and late tracheostomy were defined as $\leq 7$ days and $>7$ days, respectively, but the time point from which tracheostomy was measured was not specified [34]. Two studies utilized a range of $\leq 10$ days and $>10$ days [35][36]. Two studies did not report the specific timing of tracheostomy [37][38]. Patient characteristics from the included studies are reported in Supplemental Appendix 7. In one study of $344 \mathrm{SCl}$ patients, 72 patients also had concomitant traumatic brain injury [34]. One study investigated outcomes of children/adolescents and thus consisted of patients <18 years old [30].

\section{Quantitative Data Synthesis}

\section{Primary Outcome}

A summary of the study results is included in Supplemental Appendix 8. Early tracheostomy was not found to be associated with short-term mortality (RR $0.84,95 \% \mathrm{Cl} 0.39$ to $1.79 ; \mathrm{p}=0.65 ; 10$ studies; $\mathrm{n}=2,072 ; 125$ events; $\left.\right|^{2}=52 \%$; Figure 2, Table 4). Flanagan et al. also measured 90 -day mortality with a mortality rate of $6.3 \%$ in the early tracheostomy group and $3.5 \%$ in the late tracheostomy group [28]. In addition to hospital mortality, Jeon et al. also reported ICU mortality (2.6\% and $4.7 \%$ for the early and late tracheostomy groups, respectively) [36].

\section{Subgroup Analyses}

There was no difference in mortality between early and late tracheostomy when a subgroup analysis of study publication year (within the last 5 years versus older) was performed ( $p=0.58 ; 10$ studies; $n=2,072 ; 125$ events; $I^{2}=0 \%$ ). Further planned subgroup analyses could not be completed due to insufficient data.

\section{Secondary Outcomes}

Secondary outcomes are reported in Table 4. Early tracheostomy was found to be associated with reduced mean duration of mechanical ventilation by 13.91 days ( $95 \% \mathrm{Cl}-6.70$ to $-21.11 ; \mathrm{p}=0.0002 ; 10$ studies; $\mathrm{n}=855 ; \mathrm{I}^{2}=96 \%$; Supplemental Appendix 10 ), reduced mean ICU LOS by 10.20 days (95\% Cl

-4.66 to $-15.74 ; p=0.0003 ; 10$ studies; $n=855 ; I^{2}=90 \%$; Supplemental Appendix 11 ), as well as reduced mean hospital LOS by 7.39 days (95\% $\mathrm{Cl}-3.74$ to -11.03; $p<0.0001 ; 8$ studies; $n=423 ; I^{2}=3 \%$; Supplemental Appendix 12). Early tracheostomy was also associated with decreased incidence of VAP (RR $0.86,95 \% \mathrm{Cl} 0.75$ to $0.98 ; \mathrm{p}=0.08 ; 10$ studies; $\mathrm{n}=2,043 ; 691$ events; $\mathrm{I}^{2}=41 \%$; Supplemental Appendix 13 ) as well as the number of tracheostomyassociated complications with early tracheostomy (RR 0.08, 95\% Cl -0.01 to $-0.15 ; \mathrm{p}=0.02 ; 8$ studies; $\mathrm{n}=812 ; 158$ events; $\mathrm{I}^{2}=60 \%$; Supplemental Appendix 14). The other secondary outcomes that we were unable to find data on included long-term benefits such as quality of life measures as well as time to phonation.

\section{Qualitative Assessment of Additional Secondary Outcomes}

Bellamy et el. reported over 20 years experience at a single trauma centre of respiratory complications in SCI patients with quadriplegia. Twenty-eight tracheostomies performed within 3 days of injury were associated with 39 pulmonary complications and 14 deaths, while 4 cases of tracheostomy performed after 3 days were associated with 24 pulmonary complications and 1 case of death [26]. Mortality in this study was measured at 1 year and thus considered a long-term outcome; other than the study performed by Babu et al., which measured mortality at 1 year for the total study population, this was the only study to report long-term mortality [24]. Only 1 study reported duration of sedation and found that there was no significant difference for patients who underwent early versus late tracheostomy (14.4 \pm 10.4 days vs. $10.5 \pm 7.1$ days, respectively, $p=0.283)[25]$. The same study also found that timing of tracheostomy did not affect time to initiation of oral nutrition [25]. Vitaz et al. found that implementation of a clinical pathway, including the placement of a tracheostomy approximately 4 days following injury, was associated with a decreased number of both decubitus ulcers and stage III ulcers (25\% and $0 \%$, respectively, in the clinical pathway group compared to $54 \%$ and $14 \%$, respectively, in the control group) [33]. In a study investigating the impact of performing tracheostomy prior to anterior cervical fusion, three patients who underwent tracheostomy within 7 days of their injury experienced a deep vein thrombosis (DVT), while two patients who underwent tracheostomy after 7 days experienced a DVT [39]. One patient in the late tracheostomy also experienced post-operative decubitus ulcers. In 29 patients with traumatic cervical SCl, late (>24 hours after injury) tracheostomy was associated with decreased time to decannulation compared to early (<24 hours after injury) tracheostomy (35.0 (14-46) days vs. 42.0 (23-104) days, respectively) [40]. In contrast, Flanagan et al. found that early tracheostomy was associated with fewer days to decannulation compared to late tracheostomy $(53.0 \pm 28.1$ vs. $74.3 \pm 45.8$ days, $p<0.05)$ when ASIA Impairment Scale and level of neurological injury were controlled for [28]. 


\section{Patient and surgical factors associated with timing of tracheostomy}

Analysis of spinal cord injury level and timing of tracheostomy found earlier tracheostomy was more likely performed in patients with a thoracic SCI compared to cervical SCI (RR $1.56,95 \% \mathrm{Cl} 1.10$ to $2.21 ; \mathrm{p}=0.01 ; 2$ studies; $\mathrm{n}=367 ; 172$ events; $\mathrm{I}^{2}=0 \%$ ). Evaluating specific SCI levels, there was a trend towards early tracheostomy in patients with a SCl at or below C5, compared with a SCl above C5 (RR 1.29, $95 \%$ Cl 0.97 to 1.72; p = 0.08; 4 studies; $n=$ 1,$243 ; 352$ events; $\left.I^{2}=43 \%\right)$. There was a trend towards male sex associated with early tracheostomy $(\mathrm{RR} 1.12 ; 95 \% \mathrm{Cl} 0.98$ to $1.29 ; \mathrm{p}=0.10 ; 11 \mathrm{studies;} \mathrm{n}$ $=2106 ; 732$ events; $I^{2}=12 \%$ ). In terms of type of tracheostomy procedure, there was no difference in the timing of tracheostomy when performing a surgical tracheostomy compared to percutaneous tracheostomy (RR $1.09,95 \% \mathrm{Cl} 0.90$ to $1.32 ; \mathrm{p}=0.36 ; 5$ studies; $\mathrm{n}=609 ; 284$ events; $\mathrm{I}^{2}=0 \%$ ). Finally, there was no difference in the timing of tracheostomy in patients that received a posterior spine fixation compared to an anterior fixation (RR $1.14,95 \% \mathrm{Cl}$ 0.60 to $2.14 ; p=0.69 ; 2$ studies; $n=320 ; 95$ events; $\left.I^{2}=6 \%\right)$.

\section{Discussion}

In this systematic review and meta-analysis of patients with acute cervical or thoracic traumatic SCl, we found that early tracheostomy, as compared to late tracheostomy, is not associated with improvements in short-term mortality, however it is associated with a decreased duration of mechanical ventilation, ICU LOS, and hospital LOS. Early tracheostomy was also associated with a reduced incidence of ventilator-associated pneumonia and tracheostomy-related complications.

There is an extensive array of literature investigating the timing of tracheostomy in general critically ill populations. Although multiple cohort studies have shown that early tracheostomy may reduce the duration of MV and LOS, shorten the duration of sedation and lower the incidence of VAP, larger randomized controlled trials have established that a strategy of routinely performing early tracheostomies confers no survival benefit and may result in excess procedures [41-45]. Several recent systematic reviews also found that early tracheostomy (within 7-10 days) does not reduce mortality, in addition to finding no effect on the duration of mechanical ventilation or intensive care stay in a general critical care population [46-48]. conflicting results regarding the incidence of VAP and duration of sedation [46-48]. The indications for endotracheal intubation, mechanical ventilation and the need for a tracheostomy vary considerably between the heterogeneous mix of critically ill patients included in these studies. Early tracheostomy may help specific subgroups of critically ill populations. For example, patients with acute brain injury typically require airway protection for depressed airway reflexes, rather than respiratory failure. A recent meta-analysis of RCTs, including only patients with severe acute brain injury, showed that early tracheostomy results in decreased long-term mortality, duration of MV and ICU LOS [49].

The ongoing respiratory care needs for the homogeneous critically ill population with acute $\mathrm{SCl}$ are unique. They require a tracheostomy for the provision of prolonged mechanical ventilation due to the high incidence of respiratory complications, including atelectasis, pneumonia, and ventilatory failure following an SCI [1]. They also require an airway conduit to maintain pulmonary hygiene and suctioning due to the accumulation of secretions from the combined loss of sympathetic innervation, resulting in increased bronchial tone and mucous secretions, and expiratory musculature and ability to cough [50]. Our meta-analysis included data from only critically ill patients with cervical and high thoracic SCl. This patient population may have unique and competing considerations regarding tracheostomy that impact the timing of tracheostomy as well as subsequent outcomes. These patients often required prolonged mechanical ventilation or respiratory care for pulmonary hygiene which may favour early tracheostomy, but also have specific surgical and anatomic considerations which impact the ability to perform this procedure promptly due to concerns over surgical site infection.

Multiple factors may contribute to the lack of consensus regarding the timing of tracheostomy in patients with acute SCl. The necessity of cervical spine fixation surgery in cases of SCl has historically resulted in delayed tracheostomy due to the perceived risk of cross-contamination between the two incision sites [39][51]. However, we found that early tracheostomy prior to, or just after, anterior cervical spine fixation surgery did not result in an increased rate of tracheostomy-associated complications, including wound infection (stoma cellulitis and cervical site wound infection) (Supplemental Appendix 14) [39][52-55]. It should be noted that one study found that patients were more likely to develop a posterior incision site infection compared to an anterior one (OR 18.97, 95\% Cl 2.31 to 155.54)[53]. However, this study appears to be very small with wide confidence intervals, single center and possibly not generalizable. Additionally, there has been limited published data regarding optimal timing of tracheostomy in SCl patients, with single studies reporting on various different outcomes; several studies have only briefly explored tracheostomy timing within the broader context of identifying factors that predict the need for tracheostomy [56][57]. In the most recent clinical practice guidelines for management of spinal cord injury published in 2005 , there is no recommendation of the optimal timing of tracheostomy in patients expected to require prolonged MV. Thus, the timing of tracheostomy remains highly variable, with it often being delayed until ventilator weaning and extubation have been attempted (although a primary tracheostomy as opposed to a secondary tracheostomy following extubation failure may decrease ICU mortality and LOS) [58].

The interpretation of these findings must consider the heterogeneity between studies. Clinical heterogeneity likely exists due to 1) patient selection of ASIA Impairment Scale and illness severity scores (e.g., APACHE II or SOFA), and age, which is known to be associated with duration of MV and ICU stay 
in SCl patients, and 2) variability in cointerventions between studies. Important co-interventions in SCl patients include protocols or algorithms for liberation from mechanical ventilation. The use of mechanical insufflation-exsufflation in the liberation process, venous thromboembolism prophylaxis, and adherence to repositioning protocols to prevent the development of decubitus ulcers which are known to be associated with duration of MV and ICU/hospital LOS and mortality in SCI patients. We were not able to complete a sensitivity analysis to adjust for these factors in the included studies to determine whether such co-interventions impacted on the pooled estimate of effects on duration of MV and ICU/hospital LOS.

This systematic review synthesizes the current data regarding optimal timing of tracheostomy in acute $\mathrm{SCl}$ patients. Strengths of this review include the comprehensive study protocol, rigorous methodology, and transparent reporting process. Data were individually collected by two reviewers to limit bias, and the quality of studies was analyzed using a validated quality assessment tool. Limitations of this study include the heterogeneity between studies, the inclusion of small single centre studies, percutaneous and surgical techniques, different timings of early tracheostomy (all within 10 days of intubation), and mixed cervical and thoracic level SCl populations. However, it should be noted that the effect of percutaneous versus open would likely not bias the estimates as most of the duration of MV and ICU/hospital LOS would be driven by compromised ventilatory mechanics and VAP development.

Future research could look more specifically at quality of life (QOL) or other patient-reported outcome measures following tracheostomy in patients with $\mathrm{SCl}$. One study included in this systematic review investigated QOL outcomes and found that the number of days until initiation of oral nutrition was not significantly different between the early and late tracheostomy group [25]. A prior study examining dysphagia in SCl patients found that those patients without dysphagia experienced a mean orotracheal intubation duration prior to tracheostomy of 10.0 days, versus 16.9 days for those with dysphagia [59]. It also found that those patients with dysphagia experienced a higher rate of VAP compared to those without dysphagia (58\% vs. $9 \%$ ). In another study included in this review, one case of vocal cord dysfunction was noted [30]. Additionally, researchers at the Johns Hopkins Hospital developed a validated QOL questionnaire for mechanically ventilated ICU patients and found that those who underwent early tracheostomy compared to late tracheostomy had higher scores on the questionnaire [60]. Further investigation into QOL measures, and factors that impact those measures including the ability to phonate and swallow, should be conducted. Additionally, the long-term effects of early versus late tracheostomy remains unclear, with only one study found that investigated long-term mortality [26].

\title{
Conclusions
}

This systematic review suggests early tracheostomy (within 7 days of injury, intubation, or surgery) in acute SCI patients reduces MV duration, ICU and hospital LOS, VAP, and tracheostomy-related complications. However, early tracheostomy was not associated with short-term mortality. The impact of tracheostomy timing on long-term outcomes in SCl patients, including mortality, patient comfort and quality of life, warrants further study. Randomized controlled trials are necessary to establish the optimal timing of tracheostomy, understand patient selection considering the injury level and severity, and inform evidence-based guidelines for critically ill patients with acute SCl.

\section{Supplemental Digital Content}

\author{
Supplemental Appendix 1 - Search Strategy
}

Supplemental Appendix 2 - Sensitivity Analysis of Database Search

Supplemental Appendix 3 - Data Extraction Sheet

Supplemental Appendix 4 - Data Quality Analysis

Supplemental Appendix 5 - Definitions of Outcome Measures

Supplemental Appendix 6 - Summary of 'Timing' Definitions

Supplemental Appendix 7 - Patient Characteristics of Included Studies

Supplemental Appendix 8 - Summary of Results

Supplemental Appendix 9 - Subgroup Analysis Short-Term Mortality

Supplemental Appendix 10 - Duration of Mechanical Ventilation

Supplemental Appendix 11 - ICU Length-of-Stay

Supplemental Appendix 12 - Hospital Length-of-Stay

Supplemental Appendix 13 - Incidence of Ventilator-Associated Pneumonia 


\section{List Of Abbreviations}

$\mathrm{SCl}$ = spinal cord injury; $\mathrm{MV}=$ mechanical ventilation; $\mathrm{RR}=$ risk ratio; $\mathrm{Cl}$ = confidence interval; $\mathrm{MD}=$ mean difference; $\mathrm{NOS}$ = Newcastle-Ottawa Scale; $\mathrm{ICU}$

= intensive care unit; VAP = ventilator-associated pneumonia; RISMA = Preferred Reporting Items for Systematic Reviews and Meta-Analyses; CENTRAL = Cochrane Central Register of Controlled Trials; RTC = randomized controlled trial; LOS = length of stay; DVT = deep vein thrombosis; ASIA: American Spinal Cord Injury Association; APACHE II = Acute Physiology and Chronic Health Evaluation II; SOFA = Sequential Organ Failure Assessment

\section{Declarations}

\section{Ethics approval and consent to participate}

Not applicable

\section{Consent for publication}

Not applicable

\section{Availability of data and materials}

All data generated or analysed during this study are included in this published article [and its supplementary information files]

\section{Competing interests}

The authors declare that they have no competing interests

\section{Funding}

None

\section{Authors' contributions}

All authors read and approved the final manuscript

\section{Acknowledgements}

Not applicable

\section{References}

1. Jackson AB, Groomes TE. Incidence of respiratory complications following spinal cord Injury. Arch Phys Med Rehabil. 1994;75:270-5.

2. Harrop JS, Sharan AD, Scheid EHJ, Vaccaro AR, Przybylski GJ. Tracheostomy placement in patients with complete cervical spinal cord injuries: American Spinal Injury Association Grade A. J Neurosurg. 2004;100:20-3.

3. Reines HD, Harris RC. Pulmonary complications of acute spinal cord injuries. Neurosurgery. 1987;21:193-6.

4. Brown R, DiMarco AF, Hoit JD, Garshick E. Respiratory dysfunction and management in spinal cord injury. Respir Care. 2006;51:853-68.

5. Zimmer MB, Nantwi K, Goshgarian HG. Effect of spinal cord injury on the respiratory system: Basic research and current clinical treatment options. J Spinal Cord Med. 2007;30:319-30.

6. Ganuza J-R, Garcia Forcada A, Gambarrutta C, Diez De La Lastra Buigues E, Eugenia Merlo Gonzalez V, Paz Fuentes F, et al. Effect of technique and timing of tracheostomy in patients with acute traumatic spinal cord injury undergoing mechanical ventilation. J Spinal Cord Med. 2011;34:76-84.

7. Como JJ, Sutton ERH, McCunn M, Dutton RP, Johnson SB, Aarabi B, et al. Characterizing the need for mechanical ventilation following cervical spinal cord injury with neurologic deficit. J Trauma. 2005;59:912-6.

8. Lanig I, Peterson W. The respiratory system in spinal cord injury. Phys Med Rehabil Clin N Am. 2000;11:29-43.

9. Stevens RD, Bhardwaj A, Kirsch JR, Mirski MA. Critical care and perioperative management in traumatic spinal cord injury. J Neurosurg Anesthesiol. 2003;15:215-29.

10. Whited RE. A prospective study of laryngotracheal sequelae in long-term intubation. Laryngoscope. 1984;94:367-77.

11. Nieszkowska A, Combes A, Luyt CE, Ksibi H, Trouillet JL, Gibert C, et al. Impact of tracheotomy on sedative administration, sedation level, and comfort of mechanically ventilated intensive care unit patients. Crit Care Med. 2005;33:2527-33.

12. Heffner J. The role of tracheotomy in weaning. Chest. The American College of Chest Physicians; 2001;120:477S-481S. 
13. Marsh HM, Gillespie DJ, Baumgartner AE. Timing of tracheostomy in the critically ill patient. Chest. The American College of Chest Physicians; 1989;96:190-3.

14. Stauffer JL, Olson DE, Petty TL. Complications and consequences of endotracheal intubation and tracheotomy. Am J Med. 1981;70:65-76.

15. Mallick A, Bodenham AR. Tracheostomy in critically ill patients. Eur J Anaesthesiol. 2010;27:676-82.

16. Heffner JE. Tracheotomy application and timing. Clin Chest Med. 2003;24:389-98.

17. Berlly M, Shem K. Respiratory management during the first five days after spinal cord injury. J Spinal Cord Med. 2007;30:309-18.

18. Respiratory management following spinal cord injury: A clinical practice guideline for health-care professionals. J Spinal Cord Med. 2005;28:259-93.

19. Moher D, Liberati A, Tetzlaff J, Altman DG, Altman D, Antes G, et al. Preferred reporting items for systematic reviews and meta-analyses: The PRISMA statement. PLoS Med. 2009;6.

20. Covidence | Cochrane Community [Internet]. [cited 2020 Nov 29]. Available from: https://community.cochrane.org/help/tools-andsoftware/covidence

21. Lo CKL, Mertz D, Loeb M. Newcastle-Ottawa Scale: comparing reviewers' to authors' assessments. BMC Med Res Methodol. $2014 ; 14$.

22. Higgins J, Thomas J, Chandler J, Cumpston M, Li T, Page M, et al. Cochrane Handbook for Systematic Reviews of Interventions version 6.1. Cochrane. 2020.

23. Romero J, Vari A, Gambarrutta C, Oliviero A. Tracheostomy timing in traumatic spinal cord injury. Eur Spine J. 2009;18:1452-7.

24. Babu R, Owens TR, Thomas S, Karikari IO, Grunch BH, Moreno JR, et al. Timing of tracheostomy after anterior cervical spine fixation. J Trauma Acute Care Surg. 2013;74:961-6.

25. Galeiras R, Mourelo M, Bouza MT, Seoane MT, Ferreiro ME, Montoto A, et al. Risk analysis based on the timing of tracheostomy procedures in patients with spinal cord injury requiring cervical spine surgery. World Neurosurg. 2018;116:655-61.

26. Bellamy R, Pitts FW, Stauffer ES. Respiratory complications in traumatic quadriplegia: Analysis of 20 years' experience. J Neurosurg. 1973;39:596600.

27. Beom JY, Seo HY. The need for early tracheostomy in patients with traumatic cervical cord injury. CiOS Clin Orthop Surg. Korean Orthopaedic Association; 2018;10:191-6.

28. Flanagan CD, Childs BR, Moore TA, Vallier HA. Early tracheostomy in patients with traumatic cervical spinal cord injury appears safe and may improve outcomes. Spine (Phila Pa 1976). 2018;43:1110-6.

29. Guirgis AH, Menon VK, Suri N, Chatterjee N, Attallah E, Saad MY, et al. Early versus late tracheostomy for patients with high and low cervical spinal cord injuries. Sultan Qaboos Univ Med J. 2016;16:458-63.

30. Holscher CM, Stewart CL, Peltz ED, Burlew CC, Moulton SL, Haenel JB, et al. Early tracheostomy improves outcomes in severely injured children and adolescents. J Pediatr Surg. 2014;49:590-2.

31. Khan M, Prabhakaran K, Jehan F, Anderson P, Con J, Lombardo G, et al. Early tracheostomy in patients with cervical spine injury reduces morbidity and improves resource utilization. Am J Surg. 2020;220:773-7.

32. Lozano CP, Chen KA, Marks JA, Jenoff JS, Cohen MJ, Weinstein MS. Safety of early tracheostomy in trauma patients after anterior cervical fusion. J Trauma Acute Care Surg. 2018;85:741-6.

33. Vitaz TW, Mcllvoy L, Raque GH, Spain DA, Shields CB. Development and implementation of a clinical pathway for spinal cord injuries. J Spinal Disord. 2001;14:271-6.

34. Kornblith LZ, Kutcher ME, Callcut RA, Redick BJ, Hu CK, Cogbill TH, et al. Mechanical ventilation weaning and extubation after spinal cord injury: A western trauma association multicenter study. J Trauma Acute Care Surg. 2013;75:1060-9.

35. Choi HJ, Paeng SH, Kim ST, Lee KS, Kim MS, Jung YT. The effectiveness of early tracheostomy (within at least 10 days) in cervical spinal cord injury patients. J Korean Neurosurg Soc. 2013;54:220-4.

36. Jeon YT, Hwang JW, Lim YJ, Lee SY, Woo KI, Park HP. Effect of tracheostomy timing on clinical outcome in neurosurgical patients: Early versus late tracheostomy. J Neurosurg Anesthesiol. 2014;26:22-6.

37. Leelapattana P, Fleming JC, Gurr KR, Bailey SI, Parry N, Bailey CS. Predicting the need for tracheostomy in patients with cervical spinal cord injury. J Trauma Acute Care Surg. 2012;73:880-4.

38. Wu H, Zhao C, Li Z, Yan J, Hao J, Li Z. Value of preventive tracheotomy in patients with acute cervical spinal cord injury. Natl Med J China. 2013;93:3762-5.

39. Northrup BE, Vaccaro AR, Rosen JE, Balderston RA, Cotler JM. Occurrence of infection in anterior cervical fusion for spinal cord injury after tracheostomy. Spine (Phila Pa 1976). 1995;20:2449-53.

40. Luo C, Yang H, Chen Y, Zhang Z, Gong Z. Respiratory nursing interventions following tracheostomy in acute traumatic cervical spinal cord injury. Cell Biochem Biophys. 2014;70:455-9.

41. Kang BH, Cho J, Lee JCJ, Jung K. Early versus late tracheostomy in trauma patients: a propensity-matched cohort study of 5 years' data at a single institution in Korea. World J Surg. 2018;42:1742-7.

42. Hsu CL, Chen KY, Chang CH, Jerng JS, Yu CJ, Yang PC. Timing of tracheostomy as a determinant of weaning success in critically ill patients: a retrospective study. Crit Care. 2005;9:46-52. 
43. Scales DC, Thiruchelvam D, Kiss A, Redelmeier DA. The effect of tracheostomy timing during critical illness on long-term survival. Crit Care Med. 2008;36:2547-57.

44. Young D, Harrison D a, Cuthbertson BH, Rowan K. Effect of early vs late tracheostomy placement on survival in patients receiving mechanical ventilation: the TracMan randomized trial. JAMA. 2013;309:2121-9.

45. Terragni PP, Antonelli M, Fumagalli R, Mangione S, Pasetto A. Early vs late tracheotomy for prevention of pneumonia in mechanically ventilated adult ICU patients: a randomized controlled trial. JAMA. 2010;303:1483-9.

46. Siempos II, Ntaidou TK, Filippidis FT, Choi AMK. Effect of early versus late or no tracheostomy on mortality and pneumonia of critically ill patients receiving mechanical ventilation: a systematic review and meta-analysis. Lancet Respir Med. 2015;3:150-8.

47. Huang H, Li Y, Ariani F, Chen X, Lin J. Timing of tracheostomy in critically ill patients: a meta-analysis. PLoS One. 2014;9.

48. Szakmany T, Russell P, Wilkes AR, Hall JE. Effect of early tracheostomy on resource utilization and clinical outcomes in critically ill patients: metaanalysis of randomized controlled trials. Br J Anaesth. 2015;114:396-405.

49. McCredie VA, Alali AS, Scales DC, Adhikari NKJ, Rubenfeld GD, Cuthbertson BH, et al. Effect of early versus late tracheostomy or prolonged intubation in critically ill patients with acute brain injury: A systematic review and meta-analysis. Neurocrit Care. 2017;26:14-25.

50. Royster R, Barboi C, Peruzzi W. Critical Care in the Acute Cervical Spinal Cord Injury. Top Spinal Cord Inj Rehabil. American Spinal Injury Association; 2004;9:11-32.

51. Ball PA. Critical care of spinal cord injury. Spine (Phila Pa 1976). 2001;26:70-3.

52. Bagley J, Owens T, Hazzard M, Babu R, Huang K, Isaacs R, et al. Timing of tracheostomy after anterior cervical discectomy and fusion. Annu Sci Meet Am Assoc Neurol Surg. 2013.

53. Berney S, Opdam H, Bellomo R, Liew S, Skinner E, Egi M, et al. An assessment of early tracheostomy after anterior cervical stabilization in patients with acute cervical spine trauma. J Trauma - Inj Infect Crit Care. 2008;64:749-53.

54. O’Keeffe T, Goldman RK, Mayberry JC, Rehm CG, Hart RA. Tracheostomy after anterior cervical spine fixation. J Trauma - Inj Infect Crit Care. 2004;57:855-60.

55. Romero-Ganuza J, Gambarrutta C, Merlo-Gonzalez VE, Marin-Ruiz MA, Diez De La Lastra-Buigues E, Oliviero A. Complications of tracheostomy after anterior cervical spine fixation surgery. Am J Otolaryngol. 2011;32:408-11.

56. Jones TS, Burlew CC, Johnson JL, Jones E, Kornblith LZ, Biffl WL, et al. Predictors of the necessity for early tracheostomy in patients with acute cervical spinal cord injury: A 15-year experience. Am J Surg. 2015;209:363-8.

57. McCully BH, Fabricant L, Geraci T, Greenbaum A, Schreiber MA, Gordy SD. Complete cervical spinal cord injury above C6 predicts the need for tracheostomy. Am J Surg. 2014;207:664-9.

58. Umei N, Atagi K, Hideki S. Outcomes with tracheostomy without extubation versus those with tracheostomy after reintubation. Crit Care Med. 2013;41:A101.

59. Abel R, Ruf S, Spahn B. Cervical spinal cord injury and deglutition disorders. Dysphagia. 2004;19:87-94.

60. Pandian V, Thompson CB, Feller-Kopman DJ, Mirski MA. Development and validation of a quality of life questionnaire for mechanically ventilated intensive care unit patients. Crit Care Med. 2015;43:142-8.

\section{Tables}

Table 1: Summary of characteristics of included studies 


\begin{tabular}{|c|c|c|c|c|c|c|c|}
\hline Study & Country & Centres & $\begin{array}{l}\text { Study population/ } \\
\text { type of ICU }\end{array}$ & $\begin{array}{l}\mathrm{N} \\
(\mathrm{SCl})\end{array}$ & $\begin{array}{l}\text { Timing of } \\
\text { Early } \\
\text { tracheostomy }\end{array}$ & $\begin{array}{l}\text { Timing of } \\
\text { Late } \\
\text { tracheostomy } \\
\text { or prolonged } \\
\text { intubation }\end{array}$ & $\begin{array}{l}\text { Time of primary } \\
\text { mortality endpoint }\end{array}$ \\
\hline $\begin{array}{l}\text { Babu } \\
2013\end{array}$ & USA & $\begin{array}{l}\text { SC (Duke } \\
\text { University } \\
\text { Medical } \\
\text { Center) }\end{array}$ & $\begin{array}{l}\text { Anterior cervical } \\
\text { spine fixation and } \\
\text { trach in same } \\
\text { hospitalization } \\
\text { (SCl (18), DDD } \\
(2))\end{array}$ & 20 & $\begin{array}{l}\leq 6 \text { days } \\
(n=9)\end{array}$ & $\begin{array}{l}\text { LT } \\
\text { Days 7-12 } \\
(n=9)\end{array}$ & $\begin{array}{l}\text { Hospital and median } \\
\text { follow-up of } 12.5 \\
\text { months }\end{array}$ \\
\hline $\begin{array}{l}\text { Bellamy } \\
1973\end{array}$ & USA & $\begin{array}{l}\text { SC (Los } \\
\text { Angeles } \\
\text { County } \\
\text { Hospital) }\end{array}$ & $\begin{array}{l}\text { Cervical spine } \\
\text { fractures resulting } \\
\text { in quadriplegia }\end{array}$ & $\begin{array}{l}54 \text { (30 } \\
\text { patients with } \\
\text { complete } \\
\text { and } 24 \\
\text { patients with } \\
\text { incomplete } \\
\text { quadriplegia) }\end{array}$ & $\begin{array}{l}\text { Within } 3 \text { days } \\
\text { of injury } \\
(n=28)\end{array}$ & $\begin{array}{l}\text { After } 3 \text { days } \\
\text { of injury } \\
(n=4)\end{array}$ & $\begin{array}{l}\text { Within first year of injury } \\
\text { * Within } 14 \text { days of } \\
\text { injury was also included } \\
\text { but does not allow for } \\
\text { timing of tracheostomy } \\
\text { to be analyzed (only } \\
\text { looked at effect of } \\
\text { administration of } \\
\text { corticosteroids) }\end{array}$ \\
\hline Beom 2018 & $\begin{array}{l}\text { South } \\
\text { Korea }\end{array}$ & $\begin{array}{l}\text { SC (Chonnam } \\
\text { National } \\
\text { University } \\
\text { Hospital) }\end{array}$ & $\begin{array}{l}\text { Surgery for } \\
\text { traumatic cervical } \\
\text { SCI w/ motor } \\
\text { weakness }\end{array}$ & $\begin{array}{l}49(22 \mathrm{w} / \\
\text { trach) (27 in } \\
\text { non-trach } \\
\text { group, } \\
\text { intubation } \\
\text { removed } \\
\text { within } 4 \text { days } \\
\text { of surgery) }\end{array}$ & $\begin{array}{l}\leq 7 \text { days } \\
(n=10)\end{array}$ & $\begin{array}{l}\text { LT } \\
>7 \text { days } \\
(n=12)\end{array}$ & NR \\
\hline $\begin{array}{l}\text { Choi } \\
2013\end{array}$ & $\begin{array}{l}\text { South } \\
\text { Korea }\end{array}$ & $\begin{array}{l}\text { SC } \\
\text { (Neurosurgery } \\
\text { department at } \\
\text { Busan Paik } \\
\text { Hospital) }\end{array}$ & $\begin{array}{l}\text { Traumatic cervical } \\
\text { spinal cord injury }\end{array}$ & 21 & $\begin{array}{l}\text { Day } 1-10 \\
(n=10)\end{array}$ & $\begin{array}{l}\mathrm{LT} \\
>10 \text { days } \\
(\mathrm{n}=11)\end{array}$ & NR \\
\hline $\begin{array}{l}\text { Flanagan } \\
2018\end{array}$ & USA & $\begin{array}{l}\mathrm{SC} \text { (single one } \\
\text { trauma center) }\end{array}$ & $\begin{array}{l}\text { Traumatic cervical } \\
\mathrm{SCl}\end{array}$ & 70 & $\begin{array}{l}\leq 7 \text { days } \\
(n=37)\end{array}$ & $\begin{array}{l}\text { LT } \\
>7 \text { days } \\
(n=33)\end{array}$ & $\begin{array}{l}\text { In-hospital mortality and } \\
90 \text {-day mortality }\end{array}$ \\
\hline $\begin{array}{l}\text { Galeiras } \\
2018\end{array}$ & Spain & $\begin{array}{l}\text { SC } \\
\text { (specialized } \\
\text { hospital w } \\
\text { spinal cord } \\
\text { injury unit) }\end{array}$ & $\begin{array}{l}\text { Adults with } \mathrm{SCl} \\
\text { above level D1 }\end{array}$ & 56 & $\begin{array}{l}\text { Before } \\
\text { cervical } \\
\text { surgery or }<4 \\
\text { days after } \\
\text { surgery } \\
(n=31)\end{array}$ & $\begin{array}{l}\text { LT } \\
>4 \text { days } \\
(n=25)\end{array}$ & $\begin{array}{l}\text { Mortality during } \\
\text { admission }\end{array}$ \\
\hline $\begin{array}{l}\text { Ganuza } \\
2011\end{array}$ & Spain & $\begin{array}{l}\text { SC (National } \\
\text { Hospital of } \\
\text { Paraplegics de } \\
\text { Toledo) }\end{array}$ & $\begin{array}{l}\text { Traumatic } \mathrm{SCl} \text { at } \\
\text { cervical or } \\
\text { thoracic level }\end{array}$ & $\begin{array}{l}297 \text { (required } \\
\text { MV) } 215 \\
\text { (underwent } \\
\text { trach) }\end{array}$ & $\begin{array}{l}<7 \text { days after } \\
\text { orotracheal } \\
\text { intubation } \\
(n=101)\end{array}$ & $\begin{array}{l}\text { LT } \\
\geq 7 \text { days } \\
(n=114)\end{array}$ & $\begin{array}{l}\text { Mortality at post-cervical } \\
\text { stabilization surgery }\end{array}$ \\
\hline Guirgis 2016 & Oman & $\begin{array}{l}\text { SC (ICU of } \\
\text { Khoula } \\
\text { Hospital) }\end{array}$ & $\begin{array}{l}\text { Adult patients w/ } \\
\text { cervical SCl }\end{array}$ & 69 & $\begin{array}{l}\leq 7 \text { days } \\
(n=51)\end{array}$ & $\begin{array}{l}\text { LT } \\
>7 \text { days } \\
(n=18)\end{array}$ & ICU mortality \\
\hline $\begin{array}{l}\text { Holscher } \\
2014\end{array}$ & USA & $\begin{array}{l}\text { MC (two } \\
\text { academic level } \\
\text { I trauma } \\
\text { centers }\end{array}$ & $\begin{array}{l}\text { Traumatic injury, } \\
<18 \text { years }\end{array}$ & 91 & $\begin{array}{l}\leq 7 \text { days } \\
(n=43)\end{array}$ & $\begin{array}{l}\text { LT } \\
>7 \text { days } \\
(n=48)\end{array}$ & In-hospital mortality \\
\hline Jeon 2014 & $\begin{array}{l}\text { South } \\
\text { Korea }\end{array}$ & $\begin{array}{l}\text { SC (Seoul } \\
\text { National } \\
\text { University } \\
\text { Hospital) }\end{array}$ & $\begin{array}{l}\text { Mechanically } \\
\text { ventilated } \\
\text { neurosurgical } \\
\text { patients admitted } \\
\text { to surgical ICU, } \\
\text { underwent }\end{array}$ & $\begin{array}{l}166(125 \\
\text { included in } \\
\text { data } \\
\text { analysis) }\end{array}$ & $\begin{array}{l}<10 \text { days from } \\
\text { MV } \\
(n=39)\end{array}$ & $\begin{array}{l}\geq 10 \text { days } \\
\text { from MV } \\
(n=86)\end{array}$ & $\begin{array}{l}\text { ICU and in-hospital } \\
\text { mortality }\end{array}$ \\
\hline
\end{tabular}


tracheostomy, and

had $M V>7$ days

\begin{tabular}{|c|c|c|c|c|c|c|c|}
\hline Khan 2020 & USA & $\begin{array}{l}\text { MC (American } \\
\text { College of } \\
\text { Surgeons } \\
\text { Trauma } \\
\text { Quality } \\
\text { Improvement } \\
\text { Program (ACS- } \\
\text { TQIP) } \\
\text { database }\end{array}$ & $\begin{array}{l}\text { Adult trauma } \\
\text { patients w/ blunt } \\
\text { mechanism of } \\
\text { injury, diagnosed } \\
\text { with cervical SCl, } \\
\text { and who } \\
\text { underwent } \\
\text { tracheostomy }\end{array}$ & 1139 & $\begin{array}{l}\leq 7 \text { days after } \\
\text { injury } \\
(n=280)\end{array}$ & $\begin{array}{l}>7 \text { days after } \\
\text { injury } \\
(n=859)\end{array}$ & In-hospital mortality \\
\hline $\begin{array}{l}\text { Kornblith } \\
2013\end{array}$ & USA & $\begin{array}{l}\mathrm{MC}(14 \text { major } \\
\text { trauma } \\
\text { centers })\end{array}$ & $\begin{array}{l}\mathrm{SCl} \text { requiring } \mathrm{MV} \\
(72 \text { patients also } \\
\text { had } \mathrm{TBI})\end{array}$ & 344 & $\begin{array}{l}<7 \text { days }(48 \%) \\
(n=57)\end{array}$ & $\begin{array}{l}>7 \text { days }(52 \%) \\
(n=61)\end{array}$ & $\begin{array}{l}\text { Death due to respiratory } \\
\text { complications and } \\
\text { overall mortality (unclear } \\
\text { at what time) }\end{array}$ \\
\hline $\begin{array}{l}\text { Leelapattana } \\
2012\end{array}$ & Canada & $\begin{array}{l}\text { SC (London } \\
\text { Health Science } \\
\text { Center) }\end{array}$ & $\begin{array}{l}\text { Adults (>16) with } \\
\text { acute cervical SCI }\end{array}$ & 66 & \multicolumn{2}{|c|}{$\begin{array}{l}\text { There was a moderate positive } \\
\text { correlation between the time } \\
\text { from injury to tracheostomy and } \\
\text { the number of ventilation days } \\
\text { after injury. Average time to } \\
\text { trach was } 12.0(+/-10.1) \text { days }\end{array}$} & $>7$ days after admission \\
\hline Lozano 2018 & USA & $\begin{array}{l}\text { SC (regional } \\
\text { SCI center) }\end{array}$ & $\begin{array}{l}\text { Trauma patients } \\
\text { with cervical spine } \\
\text { trauma + treated } \\
\text { with ACF/PCF }\end{array}$ & 98 & $\begin{array}{l}\leq 4 \text { days (after } \\
\text { ACF) } \\
(n=39)\end{array}$ & $\begin{array}{l}\text { LT } \\
>4 \text { days (after } \\
\text { ACF) } \\
(n=59)\end{array}$ & In-hospital mortality \\
\hline $\begin{array}{l}\text { Romero } \\
2009\end{array}$ & Spain & $\begin{array}{l}\text { SC (National } \\
\text { Hospital of } \\
\text { Paraplegics) }\end{array}$ & Traumatic SCI & 152 & $\begin{array}{l}\text { Days 0-7 } \\
(n=71)\end{array}$ & $\begin{array}{l}>7 \text { days } \\
(\mathrm{n}=81)\end{array}$ & Subacute phase of SCl \\
\hline Vitaz 2001 & USA & $\begin{array}{l}\text { SC (University } \\
\text { of Louisville } \\
\text { Hospital) }\end{array}$ & $\begin{array}{l}\text { Cervical/ high } \\
\text { thoracic SCl }\end{array}$ & 58 & $\begin{array}{l}\text { Approximately } \\
\text { postinjury day } \\
4 \\
(n=36)\end{array}$ & $\begin{array}{l}N R \\
(n=22)\end{array}$ & NR \\
\hline Wu, 2013 & China & $\begin{array}{l}\text { SC (Third } \\
\text { Hospital of } \\
\text { Hebei Medical } \\
\text { University) }\end{array}$ & $\begin{array}{l}\text { Severe C4-C8 } \\
\text { cervical SCl }\end{array}$ & 54 & $\begin{array}{l}\text { NR } \\
(n=11)\end{array}$ & $\begin{array}{l}N R \\
(n=43)\end{array}$ & $\begin{array}{l}\text { Presumed hospital } \\
\text { mortality }\end{array}$ \\
\hline
\end{tabular}

$\mathrm{SCl}=$ spinal cord injury, $\mathrm{SC}=$ single-center, $\mathrm{LT}=$ late tracheostomy, $\mathrm{NR}=$ not reported, $\mathrm{MV}=$ mechanical ventilation, $\mathrm{MC}=$ multicenter

Table 2. Newcastle-Ottawa Scale - Cohort studies 


\begin{tabular}{|c|c|c|c|c|c|c|c|c|c|}
\hline \multirow[t]{2}{*}{ Study } & \multicolumn{4}{|l|}{ Selection } & \multirow{2}{*}{$\begin{array}{l}\text { Comparability } \\
\text { Comparability } \\
\text { of cohorts } \\
\text { based on } \\
\text { design/analysis }\end{array}$} & \multicolumn{3}{|l|}{ Outcome } & \multirow[b]{2}{*}{$\begin{array}{l}\text { Total } \\
\text { Score }\end{array}$} \\
\hline & $\begin{array}{l}\text { Representativeness } \\
\text { of intervention } \\
\text { cohort }\end{array}$ & $\begin{array}{l}\text { Selection } \\
\text { of non- } \\
\text { intervention } \\
\text { cohort }\end{array}$ & $\begin{array}{l}\text { Ascertainment } \\
\text { of intervention }\end{array}$ & $\begin{array}{l}\text { Outcome } \\
\text { not } \\
\text { present } \\
\text { at start }\end{array}$ & & $\begin{array}{l}\text { Assessment } \\
\text { of outcome }\end{array}$ & $\begin{array}{l}\text { Time } \\
\text { to } \\
\text { follow- } \\
\text { up }\end{array}$ & $\begin{array}{l}\text { Adequacy } \\
\text { of follow- } \\
\text { up }\end{array}$ & \\
\hline Babu 2013 & * & * & 0 & * & * & 0 & * & * & $6 / 9$ \\
\hline Choi 2013 & * & * & 0 & * & ** & 0 & 0 & * & $6 / 9$ \\
\hline $\begin{array}{l}\text { Flanagan } \\
2018\end{array}$ & * & * & 0 & * & ** & 0 & * & * & $7 / 9$ \\
\hline $\begin{array}{l}\text { Galeiras } \\
2018\end{array}$ & * & * & * & * & ** & 0 & * & * & $8 / 9$ \\
\hline $\begin{array}{l}\text { Ganuza } \\
2011\end{array}$ & * & * & * & * & ** & * & 0 & * & $8 / 9$ \\
\hline Guirgis 2016 & * & * & * & * & * & * & 0 & * & $7 / 9$ \\
\hline $\begin{array}{l}\text { Holscher } \\
2014\end{array}$ & 0 & * & * & * & 0 & * & 0 & * & $5 / 9$ \\
\hline Jeon 2015 & * & * & * & * & $\star \star$ & * & 0 & * & $8 / 9$ \\
\hline Khan 2020 & * & * & * & * & ** & * & 0 & * & $8 / 9$ \\
\hline $\begin{array}{l}\text { Kornblith } \\
2013\end{array}$ & * & * & * & * & * & * & 0 & * & $7 / 9$ \\
\hline $\begin{array}{l}\text { Leelapattana } \\
2012\end{array}$ & * & * & * & * & * & * & 0 & * & $7 / 9$ \\
\hline Lozano 2018 & * & * & * & * & * & * & 0 & * & $7 / 9$ \\
\hline $\begin{array}{l}\text { Romero } \\
2009\end{array}$ & * & * & * & * & ** & * & 0 & * & $8 / 9$ \\
\hline Vitaz 2001 & * & 0 & * & * & 0 & * & 0 & * & $5 / 9$ \\
\hline Wu 2013* & N/A & & & & & & & & \\
\hline
\end{tabular}

*Quality assessment not performed

Table 3. Newcastle - Ottawa Scale - Case Series

\begin{tabular}{|c|c|c|c|c|c|c|c|c|c|}
\hline \multirow[t]{2}{*}{ Study } & \multicolumn{4}{|l|}{ Selection } & \multirow{2}{*}{$\begin{array}{l}\text { Comparability } \\
\text { Comparability of } \\
\text { case/controls } \\
\text { based on } \\
\text { design/analysis }\end{array}$} & \multicolumn{3}{|l|}{ Outcome } & \multirow[b]{2}{*}{$\begin{array}{l}\text { Total } \\
\text { Score }\end{array}$} \\
\hline & $\begin{array}{l}\text { Adequacy } \\
\text { of case } \\
\text { definition }\end{array}$ & $\begin{array}{l}\text { Representativeness } \\
\text { of cases }\end{array}$ & $\begin{array}{l}\text { Selection } \\
\text { of } \\
\text { controls }\end{array}$ & $\begin{array}{l}\text { Definition } \\
\text { on } \\
\text { controls }\end{array}$ & & $\begin{array}{l}\text { Ascertainment } \\
\text { of exposure }\end{array}$ & $\begin{array}{l}\text { Same method } \\
\text { ascertainment } \\
\text { for } \\
\text { cases/controls }\end{array}$ & $\begin{array}{l}\text { Non- } \\
\text { response } \\
\text { rate }\end{array}$ & \\
\hline $\begin{array}{l}\text { Bellamy } \\
1973\end{array}$ & 0 & 0 & 0 & * & 0 & * & * & * & $4 / 9$ \\
\hline $\begin{array}{l}\text { Beom } \\
2018\end{array}$ & * & * & 0 & * & 0 & 0 & * & * & $5 / 9$ \\
\hline
\end{tabular}

Table 4. Primary and Secondary Outcomes 


\begin{tabular}{|lllll|}
\hline Outcomes & $\begin{array}{l}\text { Number of } \\
\text { studies }\end{array}$ & $\begin{array}{l}\text { Number of patients providing } \\
\text { data }\end{array}$ & $\begin{array}{l}\text { Effect estimate [95\% } \\
\text { Cl] }\end{array}$ & $\begin{array}{l}\text { P value for effect } \\
\text { estimate }\end{array}$ \\
\hline Primary outcome & & & $\begin{array}{l}\mathbf{I}^{2} \\
(\%)\end{array}$ \\
\hline Short-Term Mortality & 10 & 2,072 & $0.84[0.39,1.79]$ & 0.65 \\
\hline Secondary outcomes & & & & 52 \\
\hline $\begin{array}{l}\text { Duration of MV } \\
\text { ICU LOS }\end{array}$ & 10 & 855 & $-13.91[-21.11,-6.70]$ & 0.0002 \\
\hline $\begin{array}{l}\text { Hospital LOS } \\
\text { Incidence of VAP }\end{array}$ & 10 & 855 & $-10.20[-15.74,-4.66]$ & 0.0003 \\
\hline $\begin{array}{l}\text { Tracheostomy-Related } \\
\text { Complications }\end{array}$ & 8 & 423 & $-7.39[-11.03,-3.74]$ & $<0.0001$ \\
\hline
\end{tabular}

${ }^{1}$ Short-term mortality is defined as mortality occurring in-hospital and reported as either ICU or hospital mortality

${ }^{2}$ Trachesotomy-related complications consisted of tracheal stenosis, peri-/paravertebral abscess, tracheoesophageal abscess, mediastinal abscess bleeding, stomal cellulitis, tracheitis, subglottic stenosis, endotracheal granuloma, glottis granuloma, tracheomalacia, arytenoid dislocation, vocal cord dysfunction, tracheostomy site infection, cervical fusion site infection, esophagocutaneous fistula, suture dehiscence

$M V=$ mechanical ventilation, LOS=length of stay, VAP=ventilator-associated pneumonia, $C l=$ Confidence interval, $I^{2}=S t u d y$ heterogeneity

\section{Figures}




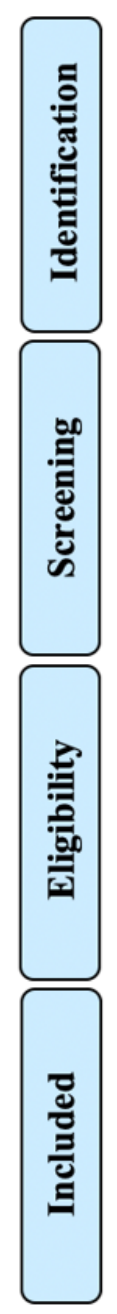

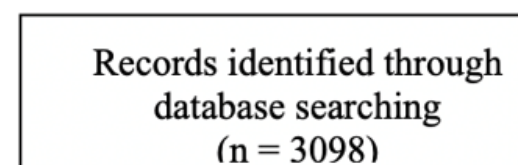

$(\mathrm{n}=3098)$
Additional records identified through other sources

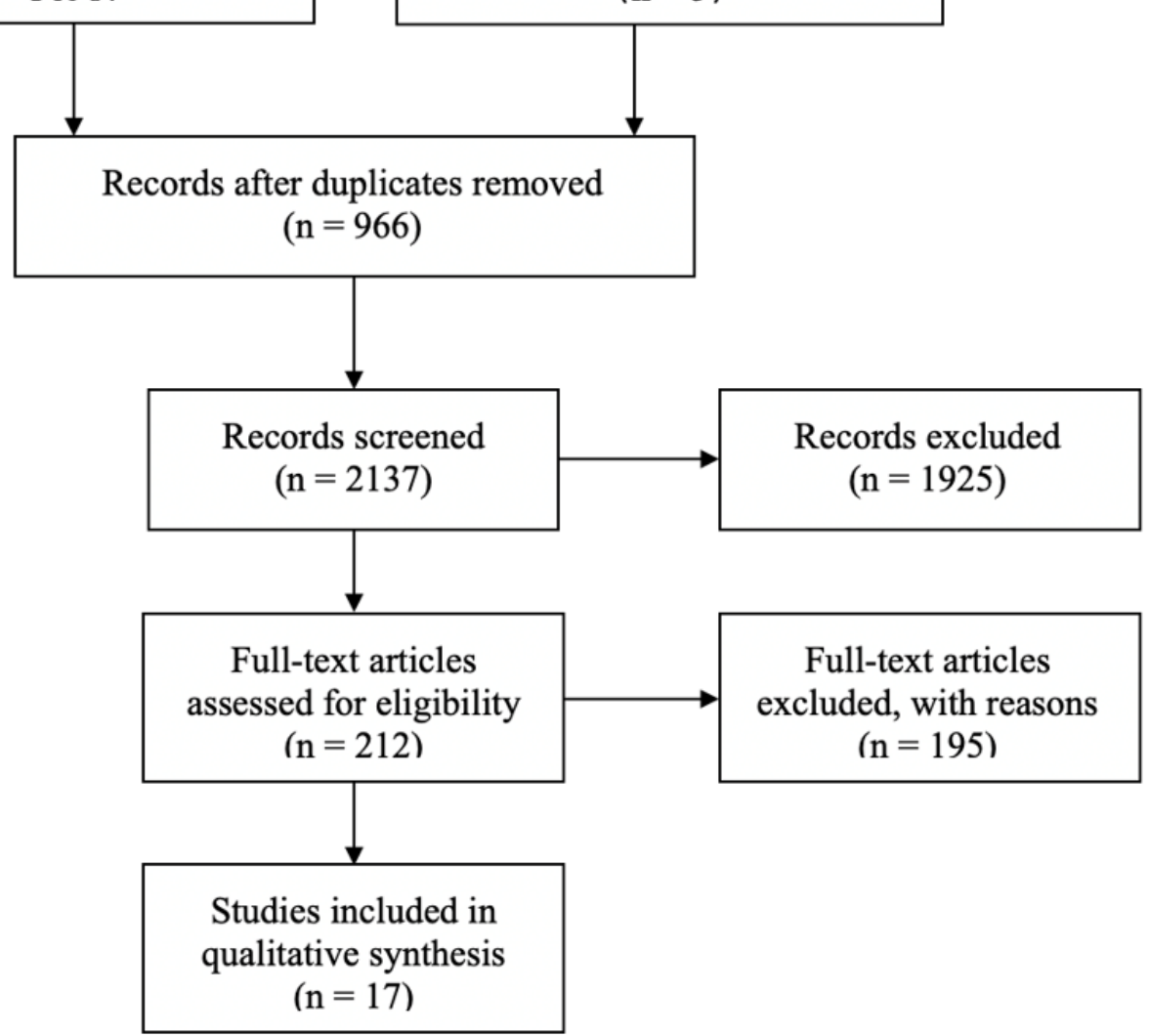

Figure 1

PRSIMA flow diagram [19]

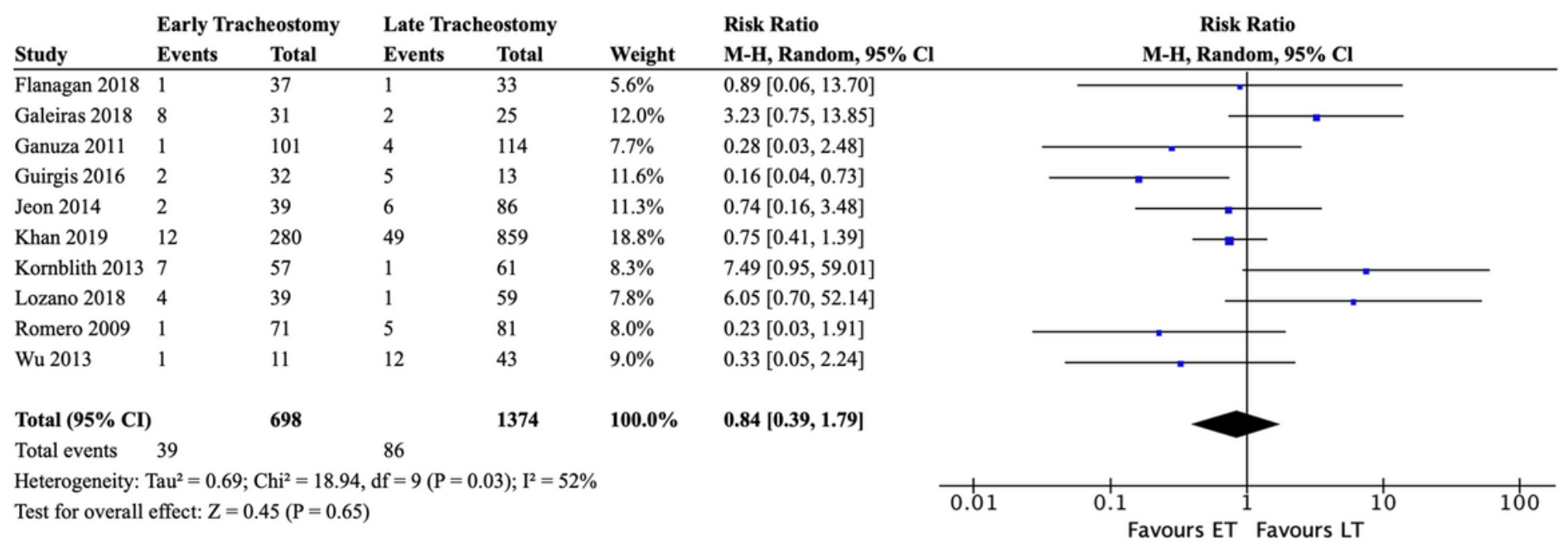

\section{Figure 2}

Random effects meta-analysis on short-term mortality, expressed as the risk ratio (RR). The blue box represents the point estimate of the study result, the black horizonal line represents the $95 \%$ confidence interval of the study result, and the black diamond represents the mean point estimate and mean confidence interval of all the studies. Flanagan et al. measured mortality at admission (ICU). Galeiras et a. measured mortality during admission. Ganuza 
et al., Kornblith et al., Romero et al., and Wu et al., did not specify the time at which mortality was measured. Guirgis et al. measured ICU mortality. Khan et al. measured in-hospital mortality. Jeon measured in-hospital mortality. Lozano measured in-hospital mortality. ET=Early tracheostomy, LT=Late tracheostomy, $\mathrm{Cl}=$ Confidence interval, $\mathrm{I} 2=$ Study heterogeneity

\section{Supplementary Files}

This is a list of supplementary files associated with this preprint. Click to download.

- SupplementalDigitalContent.docx 